\title{
TESES E DISSERTAÇÕES DE MESTRADO DEFENDIDAS
}

abril a outubro de 2000

\section{Geografia Humana}

Teses de Doutorado

\section{0 rio, a comunidade e o viver}

\section{Josué da Costa Silva}

O viver ribeirinho não é homogèneo. Hả diferenciaçōes definidas por inúmeros aspectos, sejam históricos, culturais ou econômicos. Em "O rio, a comunidade e o viver analisamos o espaço ribeirinho em sua formação, procurando: compreender o universo social e a construção do espaço; reconstruir a identidade especifica do grupo e a relação entre esta e a forma da sociedade e do espaço: caracterizar o específico sistema ribeirinho em formaçāo para compreender o universo do homem; entender os meios de subsistència do grupo; estudar a relação entre o tipo de agricultura e o ambiente; "capturar" o funcionamento do cotidiano da vila e as múltiplas relações sociais, econômicas,religiosas, políticas, ambientais; ana-

\section{Os novos rumos da política habitacional e o processo de urbanização de Dourados - MS}

\section{Mario Cezar Tompes da silva}

O presente trabalho tem por objetivo examinar os redirecionamentos sofridos pela politica habitacional e o processo de urbanizaçāo em Dourados - MS como decorrência das transformaçōes desencadeadas pelo recente processo de reestruturaçāo económica que se desdobra em escala lisar o uso e a organizaçāo do espaço; compreender o papel das representações simbólicas que o ribeirinho constrói em relaçāo ao rio.

Das comunidades ribeirinhas, uma às margens do Rio Madeira, Porto Velho, Rondonia e outra às margens do Rio Maicy, formam a base para podermos discutir a criaçāo e organizaçāo dp espaço e entendermos os aspectos básicos do viver ribeirinho: O que é natureza? O que é lugar? Como nasce o lugar? Como pensa o ribeirinho ao organizar o seu espaço? Quais os significados e valores contidos? Quais os fatores, os momentos de mudanças de um espaço obscuro, estranho, temeroso par um espaço que dá ao grupo segurança, proteção, afetividade, fartura e liberdade, ou seja, um "lugar" ? Compreender tais questōes, é compreender o universo do grupo, sua cosntruçāo de natureza, sua concepção de sociedade.

Palavras-chave: Amazônia, ribeirinho, cultura, organizaçāo do espaço, rio Madeira

global e pelo modelo de Estado Desenvolvimentista brasileiro.

Analisa-se inicialmente como a crise do modelo estatal desenvolvimenttista promoveu a derrocada das açōes habitacionais centralizadas, promovidas pelo antigo BNH, e ensejou o surgimento de sucessivas iniciativas na esfera da moradia popular sob responsabilidade do poder público local douradense, configurando, nesse processo, a constituiçāo de uma política descentralizada.

Posteriormente, através de uma análise 
histórica, que identifica as distintas etapas do processo de urbanizaçāo de Dourados, demonstra-se que as transformaçōes desencadeadas pelo contexto hodierno, dominado pelo processo de reestruturação económica e esgotamento do Estado desenvolvimentista, extrapolam os meros limites da politica habitacional e envolvem outras mais profundas que alteram o próprio padrāo de urbanização douradense.

O padrāo emergente de desenvolvimento urbano que passa a vigorar, a partir dos anos 90 , é, em boa medida, o produto do processo de expansão e diversificaçāo da agro-industrializaçāo. que, na região, funciona como principal vetor disseminador dos efeitos da reestruturação econōmica ora em vigor. As diversas e profundas conseqüèncias desse processo em Dourados produzem mudanças que apontam para o delineamento de um novo urbano.

Por último, examina-se a natureza da política habitacional descentralizada levada a efeito pelo poder público municipal, identificando, no processo de investigação, seus principais avanços, insuficiências e contradições.

Palavras-chave: Descentralização, novo padrāo de urbanização, Dourados-MS

\section{T A urbanização e a problemática ambiental no centro-oeste do Brasil: o caso de Rondonópolis - MT}

\section{José Vieira Souto}

Este trabalho visa compreender o processo de urbanizaçāo e a problemática ambiental na cidade de Rondonópolis - MT. Para desenvolver esta pesquisa, analisamos o processo urbano tomando domo totalidade o desenvolvimento da urbanização do Brasil passando pela região CentroOeste até o nosso objeto de estudo.

Nesta tese, procuramos mostrar que a partir do lugar da existência humana e da falta de qualidade de vida não pode existir condições ambientais propicias para a vida do cidadão.

Apresentamos por um enfoque dialético que o recente processo de urbanizaçāo e os pro-

\section{T A dinâmica regional recente no Brasil: desconcentração seletiva com internacionalização da economia nacional}

\section{Luiz Lopes Diniz Filho}

Este trabalho delineia uma proposta par o estudo da dinãmica recente da divisão regional blemas ambientais identificados como qualidade de vida que ocorrem na cidade de Rondonópolis, são reflexos da sociedade que criou esta cidade e que nela vive, dividida em classes sociais desiguais.

Mostramos que o processo de degradaçāo ambiental, a pobreza e a falta de uma qualidade de vida digna, tem se transformado numa série de doenças que vêm afetando uma grande parte dos habitantes desta cidade.

Procuramos mostrar nesta tese, que o lugar das carências e da pobreza é também o lugar onde se produz individuos revoltados e violentos e que a constante violència que vem ocorrendo em Rondonópolis, bem como, o uso de drogas, de armas e uma variedade de crimes deixam a vida na cidade com poucas condiçōes ambientais. Palavras-chave: Urbanização, centro-oeste, meio ambiente, violência

recente no Brasil. Com base numa discussāo metodológica sobre algumas das mais importantes linhas de pesquisa na área dos estudos regionais, estabelece como ponto de partida o conceito de "escalas geográficas" de análise e a concepção do desenvolvimetno económico como um processo condicionado por inúmeros fatores interdependentes, o qual só pode ser compreendido atra- 
vés da identificação e hierarquizaçāo desses fatores.

Assim, através de uma pesquisa histórica sobre as principais transformações econōmicas e territoriais ocorridas no pais nas últimas très décadas, a pesquisa conclui basicamente que:

a) a tendência à reduçāo das disparidades regionais no Brasil, em curso pelo menos desde 1970, tem tido continuidade nos últimos anos, ainda que de forma bastante lenta e seletiva;

b) desde os anos 80 , essa tendência já não é definida pelo processo de integração do mercado nacional, mas também pela "internacionali-

\section{T Saúde pública e política urbana - memória e imaginário social}

\section{Raul Borges Guimarāes}

O presente trabalho é uma contribuiçāo para o entendimento da natureza política da saúde pública, em uma perspectiva geográfica. Os serviços de saúde sāo considerados uma rede de sociabilidade organizada pelo discurso, na qual sāo incorporadas as noçōes de imaginário social e de memória, bem como suas implicaçōes para a epistemologia do lugar social. Em um contexto de profunda heterogeneidade na distribuiçāo de

\section{Transformações da rede urbana do norte do Paraná: estudo comparativo de três centros}

\section{Tània Maria Fonseca}

O presente trabalho tem como objetivo analisar a nova funcionalidade de trēs cidades da rede urbana no norte do Paraná: Jacarezinho, Cornélio Procópio e Cianorte. Mais especificamente, um estudo comparativo de três centros de modo a enterdermos o processo de mudança da rede urbana, ou seja, como as cidades, em novos zaçāo" da economia brasileira;

c) esse processo de "internacionalizaçāo" nāo se manifesta sob a forma de uma desarticulaçāo do mercado nacional, ainda que cirando alguns focos de dinamismo nas áreas que concentram atividades com claras vantagens competitivas internacionais.

Essas conclusōes permitem descrever sinteticamente as principais tendéncias da divisāo regional do trabalho, sobretudp a aprtir de 1985. mediante a expressão "desconcentraçāo seletiva com 'internacionalização da economia nacional" Palavras-chave: Regiāo, território,

equipamentos coletivos, como é o caso das cidades brasileiras, observou-se a variabilidade de articulações realizadas, ao longo do tempo, pelos diversos atores sociais envolvidos nessa rede.

Nos limites do poder local de Presidente Prudente, essas relaçōes foram codificadas em termos de fortalecimento da assistência médica e da expansāo da beneficência. Encontram-se aí matrizes do pensamento conservador das lideranças políticas que detém o comando da politica de saúde no nivel municipal.

Palavras-chave: Geografia da saúde. saúde pública, memória urbana

contextos, tem alterada sua funcionalidade e suas atuais inserçōes na rede.

Para tanto realizamos dois cortes temporais. O primeiro é da década de 1960, quando os centros urbanaos se apresentam como localidades centrais de nivel subregional inseridos na rede urbana caracterizada segundo um modelo hierárquico do tipo christalleriano. O outro corte temporal refere-se ao final dos anos 1990, quando os centros urbanos se apresentam bastante diferen. ciados entre si.

O município de Jacarezinho tornou-se sucro-alcooleiro e pecuarista, enquanto a cidade per- 
deu muitas funçōes, com sucessiva perda de rendas e lucros auferidos localmente.

Cornélio Procópio apresenta uma dinàmica funcional muito mais complexa que a primeira e atrelada ao controle que realiza sobre a produçāo agropecuária. Pelas cooperativas agrárias e empresas transnacionais a cidade está inserida em relaçōes internacionais de comercialização das commodities. Mão somente por estas, mas também, por uma produçāo voltada ao mercado externo e interno.

Cianorte, por sua vez, tornou-se uma cidade especializada na produção industrial confeccionista, envolvendo elevada mão-de-obra, núme-

\section{Influência dos diferentes tipos de uso da terra em bacias hidrográficas sobre sistemas aquáticos da margem esquerda do reservatório de Tucuruí - PA}

\section{Waterloo Pereira Filho}

Este trabalho representa uma avaliação das relaçōes entre os ecossistemas terrestres e aquáticos para uma parte do Reservatório de Tucurui. Foram utilizadas bacias hidrográficas como unidades representantes dos sistemas terrestres e seus respectivos compartimentos aquáticos, como áreas amostrais do reservatório. As variáveis do sistema terrestre (floresta, pasto sujo e pasto limpo) e a variável do sistema aquático (infestação de macrófitas aquáticas) foram extraidas de imagens Thematic Mapper (TM) do satélite LANDSAT-5 nas datas de 1988 e 1994. Estas variáveis foram incor-

\section{- Agricultura brasileira: a produção de alimentos}

\section{Diva Maria de Faria Burnier}

A tese trata da produção de alimentos na agricultura brasileira. Em sua parte retrospectiva, ro de estabelecimentos e geraçāo de rendas. Por intermédio desta produçāo, a cidade está inserida no mercado consumidor nacional. Adicionalmente, apresenta diversificado setor terciário de atendimento de demandas da produção da população.

Estas três cidades apresentam inserçōes distintas na rede urbana norte-paranaense que no momento atual caracteriza-se pela complexidade mediante diferenciação cada vez mais intensa entre os centros, e diversidades de integraçāo interna e externa atrelada a uma mais complexa divisāo territorial do trabalho.

Palavras-chave: Rede urbana, transformaçōes funcionais, cidades pequenas

poradas a um banco de dados gerenciado pelo SPRING, onde foram realizadas operaçōes de geoprocessamento necessárias à otenção de novas informaçōes, no ambiente aquático foram ainda medidas as variávies Nitrogēnio total, Fósforo total, Clorofila a, Condutividade Elétrica, Totais de Sedimentos em Suspensão e profundidade do disco de Secchi em periodo seco e chuvoso. Os resultados mostraram que, com o tempo, o sistema aquático passou a apresentar mais intensamente dependéncia daqueles sistemas terrestres que sofreram, principalmente, diminuiçāo na proteçāo do solo, como o desmatamento. Observou-se a tendência de, em bacias com imensas e recentes alteraçōes do uso da terra, ocorrer aumento no tempo de reação dos sistemas aquáticos retardando a obtenção de seu estado de equilíbrio.

Palavras-chave: Sensoriamento remoto, limnologia, bacia hidrográfica, reservatório

o tema é abordado da Colónia ao periodo da República, até 1970, contendo também discussões sobre a modernização recente da agricultura, consumo de alimentos e um exame individualizado do desempenho dos 15 principais produtos de origem vegetal, de 1970 a 1997 Observa-se que na regiảo Norte e Nordeste predomina o plantio 
de mandioca banana e arroz. Na regiāo CentroOeste, soja e milho. Na regiāo Sudeste, os dois grupos de alimentos ficam relativamente próximos, enquanto, no Sul, tem peso significativo a produçào paranaense de milho e soja. Já no Rio Grande do Sul destaca-se a produção de arroz, que alcançou no periodo cerca de 4.6 milhōes de toneladas.

Por outro lado, verifica-se melhor distribuiçāo entre os grupos de alimentos nos estados de Santa Catarina, Rio Grande do Sul, Minas Gerais e São Paulo. Particularmente chama a atenção nesse sentido a existência em Santa Catarina de uma estrutura fundiária menos concentrada do que no restante do pais, contrapondo-se, por exemplo, à monocultura do café do Espirito Santo. Rio Grande do Sul e Minas Gerais confirmam sua longa tradição de fornecedores, enquanto Sāo Paulo se destaca pela produção de batata, cebola e tomate, em razāo do alto grau de urbanização.

A parte final da tese discute o confronto entre o desempenho dos alimentos e o grau de

\section{T A Praça no contexto da cidades. $O$ caso de Maringá - PR}

\section{Bruno Luiz Domingos de Angelis}

O presente trabalho visa reconstruir nova relação de convívio entre o homem e a praça no contexto das cidades, mais especificamente na de Maringá, Estado do Paraná. Para tanto, foi realizado um estudo de caso sobre as 99 praças marin-

Terras de uso comum no Brasil. Estudo de suas diferentes formas

\author{
Nazareno José de Campos
}

Da antigüidade aos dias atuais a terra e os demais bens naturais tem suprido inumeras ne- indigência do pais que, em 1996, abrangia 21.4 milhões de pessoas, ou seja, cerca de $13,5 \%$ da populaçāo total de 157.0 milhōes. Na linha da pobreza absoluta, a situaçāo ainda é mais alarmante, atingindo 55,0 milhōes, cerca de um terço da população.

Assim, o Mapa da Fome, como é chamada a indigência, levou a açōes de distribuiçāo de cestas de alimentos por parte do governo em suas diversas instâncias, campanhas nacionais de solidariedade, trabalhos voluntários de arrecadaçāo, etc. Os números da fome, porém, sāo tão contundentes que somente uma campanha massiva seria capaz de enfrentá-los. Além disso, sem dispensar o caráter emergencial da distribuição de cestas de alimentos, faz-se necessário um programa de distribuiçāo de terras com concessāo de crédito e uma busca incessante de geração de emprego e renda.

Palavras-chave: Agricultura, produção de alimentos, consumo

gaenses, subsidiados por très levantamentos - dois quantitativos e um qualitativo - e uma enquete de opiniào. As análises efetuadas sobre as praças basearam-se em suas caracteristicas fisicas - equipamentos, estruturas, tipologia, inserção na trama urbana e mobiliário - e em seus aspectos sócios-económicos - lazer, população de rua, violència, economia informal, toponímia e politicas públicas para o setor.

Palavras chave: Espaços públicos, praças, planejamento urbano, Maringá

cessidades humanas. Embora predominasse o usufruto comum, a noção do privado passou a imperar a medida que a organizaçào social tornouse mais complexa, estendendo-se até dias de hoje.

No Brasil, como em outros paises, muitas áreas se caracterizam pela existência no passado ou no presente, de terras de uso comum, usufru- 
idas por diferentes comunidades. Tratam-se de formas diferenciadas tanto em sua gènese, quanto em seu processo de transformação ou mesmo desaparecimento em muitas áreas, o que reflete a complexidade sócio-espacial que o pais possui. Configuram-se desde as formas ligadas à interesses de comunidades próximas ou vizinhas às mesmas e que as usufruem plenamente, até aquelas que conjugam interesses da comunidade com outros extremos à ela, passando ainda por experiéncias dirigidas de uso coletivo da terra e formas de uso comum entre "nāo proprietários"

É importante salientar, que a terra de uso comum possui uma especificidade que the é pró-

\section{A cidade e a festa no interior do Nordeste: Espetáculo de poder, modernização e transformação cultural em Campina Grande - PB}

\section{Carlos Augusto Amorim Cardoso}

Esta tese analisa a formaçào de uma nova situação histórica, descrita em termos geográficos, da urbanização, do imaginário politico e da dinâmica do capital na cidade do Nordeste. A partir da experiència da festa - e dos discursos politicos que a sustentam - fornece a explanaçāo do conjunto de identidades sociais em formação no lugar urbano. Por outro lado, esboça uma teoria urbana da festa quando aborda a reproduçāo do

\section{Macanudo Taurino: uma espécie em extinção? Um estudo sobre o processo de modernização na pecuária na campanha gaúcha}

\section{Luiz Fernando Mazzini Fontoura}

O presente trabalho destina-se a levantar e desenvolver questões que tratassem de explicar e justificar a manutençāo da atividade pecuá- pria, em relaçào ao uso público da terra e demais bens. Este, é muito mais amplo e complexo.

No transcorrer do tempo, as terras de uso comum passaram a sofrer constante transformaçāo e apropriação individual chegando em muitas áreas, ao completo desaparecimento. No entanto, elas permanecem, apresentando-se como um componente importante na constituiçāo de diversos espaços rurais brasileiros, embora nem sem. pre com as caracteristicas que outrora possuiam. É também possivel se perceber, que mesmo em regióes cujas terras de uso comum, deixaram de existir, continuam a ocorrer, certos usos coletivos em locais públicos ou mesmo privados, como nos chamados "terrenos baldios" juntos às cidades.

espaço citadino na modernidade. Para tal enfoque desenvolve-se a descriçăo do carnaval fora de época em Campina Grande PB (Brasil) denominado de Micarande. Acostando-se nas entrevistas com o poder político local e em levantamentos de artigos e reportagens jornalisticas, relaciona o uso das ruas e das praças aos mecanismos de estruturação dos simulacros e das festas. Conclui que a festa se trona espetáculo e exibicionismo dos atores politicos e dos setor terciário no momento que mobiliza as forças produtivas para a $\mathrm{i}$ lusāo geral do consumo e para a instituiçāo de uma imagem fragmentada da cidade como mercadoria.

Palavras chave: Geografia urbana, cultura urbana, politica urbana

ria tradicional, contemplando também, a forma como se dá a modernizaçāo desta atividade e a inserção da Regiāo da Campanha no Rio Grande do Sul, no contexto estadual, nacional e internacional.

Começamos pela forma como se deu a ocupação do território, a sua evolução para uma atividade pecuária comercial e a sedentarizaçāo do gaủcho e a consolidação da estância. As caracteristicas do sistema de produção da pecuária e 
as relaçōes sociais que se estabelecem a partir disto, geram um modo de vida e uma racionalidade peculiares.

A mudança de paradigma na produção pecuária trabalha conjuntamente às variáveis manejo, sanidade, genética e alimentaçāo, reduzindo significativamente o tempo de abate. Isto possibi-

\section{De sem-terra a 'posseiro' a luta pela terra e a construção do território camponês no espaço da reforma agrária: 0 caso dos assentados nas fazendas Retiro e vVelha - GO}

\section{Marta Inês Medeiros Marques}

O trabalho analisa a organizaçāo social e forma de espacialização dos trabalhadores assentados nos assentamentos de Reforma Agrária Retiro e Retiro Velho -GO, nas fases de luta pela terra e luta na terra. A pesquisa teve como objetivo refletir através da perspectiva geográfica sobre as seguintes questōes: em que base se organiza a luta dos trabalhadores sem-terra e como estes reconstróem suas vidas no assentamento.

o grupo estudado se organiza e inicia a luta pela terra num contexto regional marcado pela emergència de uma série de lutas envolvendo posseiros e sem-terra a partir do final dos anos 70 e pelo apoio decisivo prestado a estes trabaIhadores pela Diocese de Goiás. A luta destes sem-terra é motivada por um projeto de vida cam. ponès e vivida como um ritual de passagem. O espaço do acampamento é construido a partir

\section{A Apropriação dos recursos hídricos e conflitos sociais: A gestāo das áreas de proteção aos mananciais da regiāo metropolitana de São Paulo}

\section{Marcos Estevan Del Prete}

A pesquisa aborda o uso de recursos hídricos na Regiāo Metropolitana de Sāo Paulo, em litou a articulaçāo da atividade com setores industriais e de distribuiçāo, integrando a indústria - pecuária - atacado (I-PA), redefinindo o papel da pecuária gaúcha. O desenvolvimento da pecuária empresarial traz uma nova relaçāo cidade-campo. Palavras-chave: Pecuária, desenvolvimento regional

da vivencia de uma comunidade utópica, mobilizada pela luta política.

A abordagem da fase de luta na terra, que teve inicio com a criaçāo do assentamento, visou apreender como eles constróem a sua relaçāo com a terra neste novo espaço a partir da análise da forma como organizam sua produçāo, a unidade familiar e as relaçōes comunitárias estabelecidas entre eles neste periodo. O que permitiu a identificaçāo de um complexo processo de mudança social que caminha no sentido da recampezinização dos trabalhadores assentados e da construção de um território camponês na área dos assentamentos, entrando em conflito com as idéias de modernidade, orientam o Programa de Reforma Agrária do Estado Brasileiro. Neste processo, que envolve aspectos objetivos e subjetivos, o aprendizado politico destes trabalhadores, realizado a partir da experiéncia de luta e de sua trajetória assentado do INCRA, constitui o principal fator de inovaçāo.

Palavras chave: Camponès, sem-terra, reforma agrária, assentamento, território, campesinidade, cultura e geografia

especial, aquele destinado ao abastecimento público que se encontra comprometido tanto pela ocupaçāo, quanto pela sobreposiçāo de outros usos incompativeis com a manutençāo de sua qualidade e quantidade.

O objetivo geral consiste em interpretar o papel que o sistema de gestão de recursos hidricos tem a desempenhar na soluçāo dos problemas relativos ao uso da água, em um ambien- 
te tão complexo quanto a área urbanizada da metrópole paulistana, em que tal sistema de gestào passa a ter uma feiçāo especial no que tange à gestão dos mananciais.

Embora a legislaçāo assegure em seus fundamentos o uso múltiplo da água priorizando, em situaçāo de escassez, o consumo humano e a dessedentação de animais, ocorrem desequilibrios no sistema. Há, certamente, uma apropriação contraditória dos recursos naturais em uma gran-

\section{Florianópolis: Um lugar em tempo de Globalizaçāo}

\section{Ewerton Vieira Machado}

A presente pesquisa trata de analisar, em conjunto, o significado relevante do atual momento da mundialização globalizante, com seus reflexos, procurando-se explicaçōes desse processo na conexão lugar-mundo para Florianópolis.

Assim, discutir através de possibilidades teórico-metodológicas fornecidas basicamente pelo paradigma de Formação Sócio-Espacial, desenvolvido pelo geógrafo Milton Santos, dimensóes da contemporaneidade florianopolitana, procurando-se mostrar aspectos de várias "geografias superpostas" em que nelas se pode identifi-

\section{T Calama - uma comunidade} no Rio Madeira

\section{Alberto Frederico Lins Caldas Filho}

Buscamos entender através de entrevistas textualizadas, uma comunidade à beira do rio Madeira-RO, chamada Calama. Uma das novas tentativas é a aplicaçāo talvez pela primeira vez de metrópole, gerando conflitos de uso que possuem, antes de tudo, raizes sociais. Por isso, antes de ser um problema de soluçào eminentemente técnica, a abordagem considera principalmente o aspecto social e espacial da questāo. Neste sentido, a pesquisa propõe investigar a ocorrência destes conflitos a partir de suas raizes, a fim de iluminar as suas formas de manifestação e avaliar os instrumentos utilizados para a gestão em uma sociedade que formula para si mesma uma imagem democrática.

car a dinàmica do lugar-regiāo e sua inserçāo no mundo atual.

Desse modo, fez-se um enfoque a partir de trajetórias da urbanizaçāo, procurando mostrar tentativas de "produçāo do lugar" associađas com a idéia de "fabricação de uma vocação". hoje vinculada predominantemente às atividades de turismo, num plano mais visível, e amplamente mercantilizada sob várias imagens midiáticas. Num outro plano, não menos importante, há tentativas de vinculações à produçāo espacial por atividades de base tecnológica, particularmente relacionadas com o meio informacional e/ ou dele decorrente.

Palavras-chave: Geografia-Florianópilos,

Geografia Humana, desenvolvimento regionalFlorianópolis (SC), turismo

na Geografia Humana, da História Oral e das técnicas de transcrição como mecanismo para aprofundamento maior na estrutura da comunidade. Tentando compreender tanto o aspecto histórico quanto o espaço e o lugar, não a partir de teorias, mas de experiência viva nas falas da comunidade. Consideramos que a partir destes procedimentos poderemos ter, na Geografia Humana, um mecanismo para realizarmos o "Humano" da 
sua "Geografia" já que partimos da experiéncia para compreendermos o lugar e seus fluxos sociais e imaginários. Integrar a fala e a experiéncia como elementos fundamentais para a compreensão e estrutura dos conceitos de espaço e lugar (tratados como dimensōes virtuais de determinada sociabilidade e dos indivíduos e grupos), é uma das pretensōes do texto. Não mais o espaço e o lugar enquanto conceitos mas, fundamentalmente, como instáncias da vivéncia. Primeiro por serem constituidos socialmente, não havendo nem espaço nem lugar fora da sociabilidade, fora da presença humana; segundo por estarem na

\section{Movimento da força de trabalho num contexto de integração acelerada do Mercosul}

\section{Luiz Carlos Batista}

Esse estudo pretende analisar o novo desenho da fronteira a partir destes processos de deslocamentos da população trabalhadora desterritorializada, investigando alguns aspectos das modificaçōes na Geografia Política que interferem na mobilidade populacional, produzindo novas territorialidades que modificam o conhecimento geográfico tradicional, a partir de um desenho da Geografia Política e Econômica está traçando para o mundo.

A generalização da mobilidade da forçade-trabalho como causa sócio-estrutural, a partir das motivaçōes e liberdades individuais dos migrantes, ganha no mundo contemporâneo novas caracteristicas a parir da exclusão de grandes contingentes da populaçāo mundial do mercado de trabalho e a sua integração precária e perversa na globalizaçào, dominada pelo modo capitalista de produçāo como um todo social, provoca novas formas de deslocamentos populacionais. simultaneamente aparecem novas restriçōes a esses deslocamentos. As pesquisas geográficas fala ao fazerem parte constitutiva da experiéncia vivida; terceiro, por tornarem um lugar conceitual a partir dessa experiência e nāo de um a priori conceitual. Do amálgama vivo da experiència com o espaço e o tempo sociais podemos, a partir das entrevistas chegar à vivência dessas percepçōes e fundar uma compreensāo mais profunda do viver o lugar. A partir da experiencia contada chegar aos múltiplos espaço vividos e com isso, alcançar, nảo os conceitos, mas uma comunidade singular.

Palavras-chave: Geografia Humana, História, História Oral, interpretação, texto, oralidade.

estão obrigadas a redefinirem os seus conceitos de migrantes, de fluxos migratórios e de políticas migratórias.

As questōes da "Globalizaçāo e Fragmentaçāo" como uma temática central na geografia, retomam o conceito de "lugar" ao considerar o fenômeno dos deslocamentos das "pessoas-sem. lugar no mundo"

Faz-se necessário um estudo sobre a emancipação das determinaçōes econômicas, sociais, culturais e territoriais, que levaram às formas empiricas destes deslocamentos dos trabalhadores, que não ocorrem apenas no espaço, mas é encontrado também entre ramos e setores da produção, concentrando-se na análise do movimento da força de trabalho num contexto de integraçāo acelerada, utilizando como estudo de caso o Mercosul.

O Mercosul constitui-se numa estratégia do Brasil, Argentina, Uruguai e Paraguai para integrar a América do Sul e diminuir os impactos do processo de globalizaçāo, que procura excluir a influéncia dos estados nacionais e das organizaçōes da sociedade civil nos mecanismos neoliberais de integração dos mercados no mundo capitalista. Palavras-chave: Integraçào, globalizaçāo, Mercosul, força-de-trabalho, território, movimentos da populaçāo 


\section{Sistema de Informaçāo Geográfica e planejamento de transporte coletivo urbano - estudo de caso: sistema integrado de transporte de Uberlândia}

\section{Denise Labrea Ferreira}

O planejamento e a gestão dos transportes urbanos são processos dinámicos, e, para que o sistema de transporte faça parte e acompanhe o processo de desenvolvimento urbano, é de fundamental importáncia que os órgãos gestores disponham de instrumentos que possibilitem a atualizaçāo do sistema de transporte de forma produtiva e eficaz. Nesse sentido, este edtudo demonstra a aplicação do Sistema de Informaçāo Geográfica - SIG como instrumental para o planejamento, gestāo e operação dos sistemas de transporte urbano, pois permite o cadastramento, a atualização e a representação da base de dados de transporte com a rapidez e a quantidade necessárias para auxiliar a tomada de decisōes. Nesse trabalho, está discussão é abordada em três momentos: primeiro, no uso do SIG como tecnologia cada vez mais necessária em órgāos de planejamento, pois, com sua evoluçāo constante, classifica-se como uma tecnologia de rápida difusão e aceitação e tem despertado o interesse dos profissionais envolvidos com o planejamento de transporte urbano e apresenta o software MapInfo como ferramenta de mapeamento eletrônico. No segundo momento, relatase a história do planejamento de transporte de Uberlândia e a escolha da cidade par a análise do uso do SIG no desenvolvimento do Sistema Integrado de Transporte, na sua implantação e monitoraçāo. No terceiro momento, usa-se o SIG no planejamento do Sistema Integrado de Transporte de Uberlância, procurando contribuir para este ser realizado como processo, auxiliando no desenvolvimento, na implantação, no acompamnhamento e na avaliaçāo constante para alcance dos objetivos propostos.

Palavras-chave: Geoprocessamento, Sistema de Informaçāo Geográfica (SIG), planejamento de transportes, Sistema Integrado de Transporte

\section{Geografia Humana}

Dissertações de Mestrado

\section{- Capim na fresta do asfalto: conflito pela terra em Conde, Zona da Mata Paraibana}

\section{Marcelo Gomes Justo}

A dissertação trata de um conflito pela terra em que houve homicidio de dois camponeses na fazenda Gurigi 2, no municipio de Conde, vizinho ao sul de João Pessoa/PB.

O método utilizado foi a etnografia do conflito em que se procurou o enfoque de várias dimensōes da disputa e analisar suas conseqüências.

Mais de setenta familias vivem no povoado e relatam que sāo descendentes de indios e de negros africanos. Estão no local há mais de quatro gerações. Logo, a ligação deles com aquela terra é dada pela ancestralidade. Viviam como "moradores de condição" desde final da década de 1940 e no começo dos anos 1980, foram ameaçados de expulsāo pelo proprietário. Resistiram numa luta que durou mais de uma década e conseguiram a desapropriação da fazenda em 1988. Mas o titulo de propriedade não havia sido emitido até dezembro de 1999. É um dos poucos casos no cenário nacional em que os camponeses foram assentados onde nasceram. A regra para o camponès é a migração, pois sofre sucessivas expropriaçōes.

A peculiaridade do caso é ter havido atuação do poder judiciário em relação aos homicidios. Com a análise dos processos penais, debateu- 
se com a literatura especializada que postula um papel determinante desse poder na contençāo da violência no campo.

Além disso, constatou-se que as organizaçōes civis ligadas aos camponeses tiveram peso

$* * *$ para que o caso chegasse aos tribunais. O histórico das organizaçōes camponesas na Paraiba ajudou a situar o caso.

Palavras chave: Conflito agrário, campesinatol, violência, Nordeste

\section{A metropolizaçāo-periferizaçāo brasileira no período técnico-ciêntifico-informacional}

\section{Eliza Pinto de Almeida}

O atual periodo histórico é caracterizado pela presença cada vez maior de conteúdos de técnica, ciência e informaçāo que atingem, em graus distintos, todas as partes do mundo e, por conseguinte, sāo também responsáveis pela remodelação de vastas áreas do território nacional.

O uso de território modifica-se, portanto, com esses novos acréscimos de ciència, tecnologia e informaçāo. A incorporação das modernizações, no pós-segunda guerra mundial à nação brasileira acelerou a urbanizaçāo da sociedade e do território. A concentração de recursos econômi-

\section{O céu e o inferno modernização, reestruturaçāo e qualidade de vida: Para uma geografia dos conflitos no centro da cidade de São Paulo}

\section{Valter Maestro de Oliveira}

O tema central de nossa dissertação sāo os conflitos nas áreas central da Cidade de São Paulo diante dos projetos de revitalização que estāo se materializando. Analisamos os projetos que sustentam-se na modernizaçāo e na reestruturação por qual a cidade passa, baseados em uma suposta melhoria da qualidade de vida.

O mapeamento dos conflitos e sua sistematizaçāo passou pela localização dos fenōmenos, pela correlaçāo das informaçōes e pela compreensão do desenvolvimento das ações que estão materializadas no cotidiano da cidade, tendo cos e de população outorgou um papel de destaque às metrópoles brasileiras. Dentro desse contexto, analisamos o processo de periferização entendido como a exclusāo social e geográfica de grandes parcelas da populaçào das modernizaçōes do pais. O uso corporativo das metrópoles brasileiras, fruto de uma valorizaçāo desigual das pessoas e dos lugares, criou uma organização territorial metropolitana que é excludente, beneficiando, sobretudo, as atividades modernas e uma minoria da populaçāo. Os subespaços das metrópoles atingidos pelas modernizaçōes exercem uma ação centrifuga, expulsando para áreas distantes das periferias ou para os intersticios das cidades àqueles que nāo podem pagar pelo ônus dessa valorização.

Palavras chave: Periferias

- conflito como o processo de resisténcia e de embate aos projetos excludentes que a cada dia reordenam esse lugares visando a re-construção do centro para atender aos interesses de um grupo minoritário, mas hegemônico da populaçāo.

Na perspectiva de realizar uma análise Geográfica, buscamos compreender a esséncia dos fenomenos, objetivando explicar como reordenamento dos lugares da cidade pode provocar um movimento de opressão, uma vez que nāo garante ao cidadāo reconhecer na paisagem da cidade seus simbolos, alienando-o, já que o transforma em um mero reprodutor de açōes, ou seja, afastando-o do direito de ser cidadāo. Lutar, planejar, resistir, vivenciar, questionar... é de certa forma a única maneira de sobreviver nesse lugar. Palavras chave: Modernizaçāo, reestruturaçāo, revitalizaçāo, conflitos, exclusāo 


\section{Centralidade e periferia na grande Sāo Paulo. Abordagem crítica sobre o morar na periferia da metrópole}

\section{Alexandre Souza da Rocha}

Vivemos num mundo de banalidades, e o banal aparece somente como reduçào da profundidade que a vida poderia ter, porém nas banalidades do dia-a-dia da metrópole é que a vida acontece. Esta pesquisa mostra uma parte destes "instantes" metropolitanos. Não um reino de liberdade, mas no aprisionamento da vida regrada pelo mundo do trabalho, temos situaçōes que podem ser a negação do absoluto do Estado e do Capital, embora a força revolucionária dessas insurreiçōes pareça diminuta. É preciso um projeto para reunir esses fragmentos e lhes dar algum sentido; aqui se trata de reconhecê-los.

O momento do morar implica o ir e vir, assim como estabelecer-se. Neste momento temos possibilidades vividas cotidianamente, não por todos e nem ao mesmo tempo, que podem estabelecer uma relaçāo diferente com o cotidiano programado ou com o infra-cotidiano.

Os lugares de auto-construçāo são também os de reunião, não só familiar, no ato de encher uma laje ou nos botecos; da mesma forma, momentos de deslocamento se apresentam tam. bém como momentos de encontro.

Palavras chave: Periferia, centralidade. metrópole, morar, cotidiano
Uso do solo e degradação ambiental na Baixada Santista (SP): o caso de São Vicente

\section{Ricardo Fernandes Faustino}

Estudou-se o município de São Vicente SP que ostenta o marco de primeira vila brasileira e achamos oportuno, nesses quinhentos anos de descobrimento do Brasil, analisarmos com um olhar geográfico as condições atuais desse lugar. Foram feitos mapas temáticos da região com o objetivo de verificar seus aspectos sócio-ambientais.

Constatou-se que embora São Vicente possa usufruir de seu quadro natural para o turismo

A cartografia ambiental para o município de São Sebastiāo - SP: análise e reflexão

\section{Paulo Ricardo Brum Pereira}

O presente estudo apresenta uma visão integrada dos elementos e fatores que compōem o e uso sustentável do manguezal, esse lugar apresenta intenso processo de degradação ambiental causado pela industrialização que caracteriza a regiāo Sudeste.

Verificou-se que a degradação é tanto ambiental quanto social e que grande parcela de sua populaçāo vive em condições precárias e insalubres. Isso se deve, em grande parte, ao modelo económico que caracterizou nosso pais nesses quinhentos anos.

Propõe-se para São Vicente um gerenciamento ambiental e social, almejando a modificaçāo do quadro atual de degradação.

Palavras-chave: Degradaçāo ambiental, manguezal, litoral

ambiente do municipio de são Sebastiāo - Estado de Sāo Paulo, através de uma cartografia ambiental. Essa representação é baseada em metodologia ainda em processo de sistematização fundamentalmente pela questão do atual estágio de desenvolvimento daquilo que, no contexto mais amplo da Cartografia, pode ser considerado como uma 
cartografia ambiental.

O município de Sāo Sebastiāo possui uma variedade bastante significativa de elementos $e$ fatores que compōem o quadro geográfico. Para alcançarmos o objetivo de produzir um estudo ambiental, analisamos uma série de informaçōes sobre as disciplinas do quadro natural (Geologia. Geomorfologia, Vegetaçāo e Climatologia) e antrópico (Histórico da ocupação, uso da terra, urbanizaçāo, apropriação de recursos). Abordamos esses temas de forma integrada através de uma perspectiva da Cartografia como um meio de comunicaçāo, preocupada perspectiva da cartografia: com a eficiência da informaçāo, a mensagem transmitida e com os potenciais usuários. Os mapas de

\section{A participaçāo da iniciativa privada na produçāo do espaço urbano: São Paulo, 1890-1911}

\section{Mônica Silveira Brito}

A presente dissertação aborda o papel da atividade empresarial privada voltada ao mercado imobiliário e à dotaçāo material da cidade de Sào Paulo, entre 1890 e 1911 .

Trata-se de analisar as condiçōes concretas de organização de tais empreendimentos e enfatizar seu papel na incorporação do processo

\section{O Bom Retiro: uma paisagem paulistana}

\section{Márcio Pereira Santos}

Nossa dissertaçāo procura oferecer uma exemplificação de como as redes atuam no espaço, fazendo uma recuperaçāo da história da produçāo espacial de uma fraçāo do espaço urbano da cidade de São Paulo, o bairro do Bom Retiro, tipos de relevo e estrutura geológica foram fundamentais para a definiçāo de très grandes sistemas ambientais que contribuiram para chegarmos ao mapa sintese de unidades ambientais. O mapa das unidades ambientais é o resultado das análises e reflexōes das caracteristicas de cada elemento e fator que compōem o ambiente do municipio, permitindo a espacialização das caracteristicas mais homogêneas.

Este estudo fornece também inidicativos através de um preliminar diagnóstico dos problemas ambientais configurados no municipio, que podem ser utilizados por setores de planejamento. Palavras-chave: Cartografia ambiental, mapa sintese

de produçāo do espaço urbano em Sāo Paulo aos circuitos de reproduçāo do capital social.

Os resultados da pesquisa empreendida permitem afirmar que a configuraçāo espacial da cidade no periodo estudado evidencia a presença, nessa área, de uma atividade empresarial organizada e circunscrita a um número relativamente restrito de empreendedores, que lançavam mào de estratégias diversas, com vistas à melhor viabilizaçāo de seus negócios.

Palavras-chave: Sāo Paulo, urbanizaçāo, mercado imobiliário, infra-estrutura urbana, propriedade fundiária

que ao longo da segunda metade do século XIX e inicio do XX teve sua "paisagem rural" metamorfeseada em "paisagem urbana" em funçào da implantaçāo de redes materiais e sociais. Redes estas originadas por exigēncia de uma dinâmica social local associada à associada à transição e a emergência das classes apegas ao poder de mando.

Palavras-chave: Paisagem, redes. partido arquitetónico, Sāo Paulo, Bom Retiro 


\section{A propriedade privada da terra e a produção de novas espacialidades na cidade de Fortaleza}

\section{Ana Cristina Mota Silva}

A pesquisa busca compreender como o processo de urbanizaçāo comporta uma sintese contraditória de elementos que aparecem na produção da cidade de Fortaleza. Assim buscou-se compreender tanto quais sảo estes elementos componentes como a relação histórica entre os mesmos. A urbanizaçāo aparece como um processo de modernizaçāo que se faz na redefinição daquilo que se coloca em atraso em relação a ela. Portanto, é a partir da realizaçāo da propriedade da terra em embate com os costumes que se realiza a construçāo de uma espacialidade própria: a cidade moderna. As determinaçōes desta materializam-se com o fechamento das cacimbas públicas, dos caminhos, com a canalizaçāo e privatização das águas públicas através da construçāo dos chafarizes ingleses, quando o chafariz como conta-gotas denuncia o acesso seletivo

\section{$* * *$}

\section{Formação territorial sul piauiense: modernização agropecuária $e$ resistência camponesa}

\section{Vicente Eudes Lemos Alves}

A expansāo da fronteira agricola envolvendo áreas de cerrado, que teve inicio na década de 60 pela regiào Centro-Oeste do Brasil chega no final da década de 70 e, principalmente na de 80 também ao Sul do Piaui. Define ali a partir de então, uma nova dinâmica sócio-territorial. As formas pelas quais vem se manifestando esse processo são o passo principal desse trabalho. Para tanto, busca-se decifrar por um lado, as transformaçōes decorrentes da instalaçāo de novos grupos interessados em desenvolver atividades agro- a um bem que é abundante. Ele materializa a programação desta abundāncia. A espacialidade des. sa forma moderna de produzir nos ajuda a compreender a potencializaçāo da cidade como negócio; esta exigiu a transformaçāo da terra em capital com a inserçāo do capital estrangeiro The Ceará Water Company Limited - como explorador de uma renda de minas e conseqüente formação de capital via serviços públicos. Assim, um segundo momento deste processo envolve a metamorfose da renda rural em renda urbana. $O$ que caracteriza este segundo momento é o fato de a captação da riqueza social através da renda da terra - como sua já citada metamorfose - realiza-se como riqueza familiar. Dai a importāncia da familia Gentil no contexto deste trabalho, já que através dela torna-se também possivel o desenvolvimento da personificação - subjetivação - de processos históricos objetivos. Por isso mesmo, pode-se afirmar que a realização da cidade se faz como negócio porque ela permite a formação de um grupo econômico familiar específico. Palavras-chave: Costumes, renda da terra, urbanização, cidade pecuárias em moldes capitalistas utilizando-se técnicas mais modernas e produzindo novas formas de ocupaçāo e uso do espaço. Busca-se avaliar por outro lado o que permanece das organizaçōes sócio-espaciais construídas historicamente pela população local cuja relação com a dinâmica da natureza se define como o fator mais importante.

Procura-se nesse trabalho, compreender de que maneira o encontro entre dois modelos de ocupaçāo e uso das terras dos cerrados piauienses comandados por grupos sócio-econômicos diferenciados tem contribuido para o aparecimento de novas modalidades de tensōes sociais naquele território.

Palavras-chave: Formação territorial, Estado, cerrados, modernizaçāo agropecuária 


\section{Espaço, tempo e memória: construção e transformação do espaço em \\ São Luiz do Paraitinga e Natividade da Serra}

\section{Maria Alice Oliva de Oliveira}

Este trabalho pretende fazer uma reflexão acerca do papel do espaço na construçāo da memória social, procurando avaliar a importância das formas espaciais para a memória do grupo.

A pesquisa foi centrada em dois municipios da Vale do Paraíba: São Luiz do Paraitinga e Natividade da Serra. O primeiro possui construçōes datadas de século XIX, período em que a cultura cafeeira foi importante em toda a área do Vale. Em 1982, todo o centro histórico foi tom- bado pelo Condephaat. Já o núcleo urbano de Matividade da Serra, cuja origem era semelhante a São Luiz do Paraitinga, foi totalmente alagado para a construção da Usina Hidrelétrica de Paraibuna e reconstruido em outra área.

No intuito de compreender a dinámica da construçào/reconstruçào espacial na área da pesquisa, bem como as imagens criadas para aquele espaço, foram analisadas algumas obras sobre o Vale do Paraiba, além do discurso do Estado para justificar as intervençōes nos dois municípios. Contrapondo-se a esses discursos, foi analisada a fala de alguns moradores, a partir da qual pode ser apreendida a memória do grupo.

Palavras-chave: Memória, espaço vivido, patrimônio histórico, história oral, percepçāo do espaço

\title{
$\infty$
}

\author{
Geografia Física \\ Teses de Doutorado
}

\section{0 holorritimo e as interaçōes trópico-extratrópico na gênese do clima e as paisagens do Mato Grosso}

\section{Denise Maria Sette}

A gênese climática e as paisagens do Mato Grosso, localizado no centro do continente sul americano, foi estudado através do conceitos de holorritmo, fundamentado nos pressupostos do paradigma holistico entre os fenomenos climáticos e a paisagem.

As interaçōes trópico-extratrópico, no tempo e no espaço foram analisadas em anos hidrológicos, um habitual (set/96 a ago/97) e o outro ano padrāo "seco" (set/97 a ago/98), incluindo o El Niño de $97 / 98$.
Da análise das cartas sinóticas ( 12 e 24:00 TMG), e da interpretaçāo de imagens infravermeIho dos satélites metereológicos (GOES e METEOSAT) correlacionadas com o mapeamento da pluviosidade diária, mensal, sazonal e anual, resultou no entendimento do ritmo e da gènese do clima.

O conhecimento produzido e acumulado no trabalho de campo (5 percursos, na estação seca e chuvosa) com medidas dos atributos climáticos e observações sobre o relevo, a vegetaçāo, os solos e a ocupaçāo humana da paisagem. foi fundamental na elaboração da sintese.

Da integraçāo de todos os resultados, elaboramos a sintese da participaçào dos sistemas atmosféricos qual atuam no Mato Grosso na estaçāo seca e na estação chuvosa, e a sintese da estrutura pluvial associada às paisagens, avalia- 
das atavas dos graus de alteraçāo antrópica da vegetação natural.

- Cartografia. Geotécnica de planejamento e gestão territorial: proposta metodológica

\section{Carlos Geraldo Luz de Freitas}

As propostas teórica e metodológica apresentadas contemplam basicamente a aplicaçāo da carta Geotécnica de planejamento e na gestảo territorial. Para tanto, foram considerados os principais tipos possiveis dessa cartografia, agrupados por atividades de uso e ocupaçāo do solo, de acordo com os principios básicos pertinentes nos trabalhos de Geologia de Engenharia.

Para aplicação do método proposto, foram elaboradas duas cartografias do municipio de Mogi Mirim, com objetivos especificos para questōes diferentes de planejamento e gestāo desse município. Resultaram em produtos distin-
Palavras-chave: Holorritmo, gênese do clima, pluviosidade, trabalho de campo, paisagem

tos, confirmando-se, assim, a hipótese de trabaIho, de que os vários tipos de Carta Geotécnica se diferem pelas múltiplas finalidades de seu uso, sendo determinados pelas questóes de ocupação do solo que se pretende resolver.

Procurou-se, também, mostrar a necessidade de complementaçāo dos conhecimentos de Geologia de Engenharia, utilizando-se de fundamentos de outras disciplinas das Geociēncias, além de áreas de Ciências Sociais e econömicas. A Carta Geotécnica, assim tratada, constitui um instrumento tecnológico interdisciplinar, cujos componentes básicos de reflexão sāo o tempo (relacionado com a dinámica dos processos do meio físico), o homem (como agente dessa dinâmica no meio em que está inserido e com seu usuário) e o espaço físico disponivel.

Palavras-chave: Carta geotécnica, planejamento

\section{Definição de unidades de fragilidade natural: uma contribuição ao planejamento ambiental do Estado de Mato Grosso}

\section{Hugo José Scheuer Werle}

Este trabalho é um estudo geoambiental que teve como objetivo a definiçāo de Unidades de Fragilidade Natural de uma área situada no centro-norte do Estado de Mato Grosso. Como fundamentaçāo teórica foi utilizada principalmente a metodologia de análise empírica da fragilidade de ambientes naturais e antropizados de Ross (1994). Tendo a geomorfologia como referência inicial para o desenvolvimento dos trabalhos, aliou-se a esta, como elementos básicos, a pedologia e a cobertura vegetal natural. Destes très temas foram elaboradas cartas temáticas na escala de $1: 250.000$ as quais tiveram suas infor- maçōes cruzadas para que se obtivesse a espacializaçāo das unidades de fragilidade. Paralelamente foi procedido o levantamento da geologia, dos aspectos climáticos, do desmatamento e da sócio-economia da área de estudo, os quais contribuiram para a caracterização ambiental das unidades. Os resultados alcançados apontam a existência de trinta e duas Unidades de Fragilidade Natural que apresentam diferenciados graus de devastação dos condicionantes naturais, gerados em funçāo da utilização desordenada dos recursos naturais. Por essa razāo a discussāo final mostra a necessidade urgente de uma politica ambiental mais ampla a qual apresente soluçōes efetivas para a preservaçāo, ou pelo me nos, para a conservação dos ambientes naturais mais fragilizados.

Palavras-chave: Geomorfologia, unidades de fragilidade natural planejamento ambiental 


\section{Diagnóstico ambiental e potencial turístico na regiáo da Mata Atlântica: o exemplo do Município de Santo Antônio do Pinhal - SP}

\author{
José Carlos Brenha
}

O objetivo deste trabalho foi analisar fatores ecológicos, sociais, econômicos e políticos. determinantes do processo singular de regeneração da Mata Atlāntica, que abrange uma área de $66,60 \mathrm{~km}^{2}$, no Município de Santo Antônio do Pinhal, Estado de Sāo Paulo, em contraposiçāo à crescente degradação que ela vem sofrendo nos últimos anos. Para este estudo, foram utilizadas técnicas de sensoriamento remoto e de cartografia automatizada digital, tais como o uso de imagens de satélite (TM Landsat, na escala de :50.000), técnicas de geoprocessamento, realizadas no Sistema de Tratamento de Imagens (SITIM) e do Sistema Geográfico de Informaçōes (SIG), desenvolvidos pelo Instituto Nacional de Pesquisas Espaciais (INPE), e cartas geradas a partir de fotografias aéreas. O trabalho de campo foi executado com dezoito diferentes áreas do município, selecionadas de forma sistemática, para o levantamento de dados e obtenção de informaçōes sobre vegetaçāo, altitude, declividade, azimute $e$ amostras de solo para compor um perfil do município em estudo. A análise dos aspectos econômicos e sociais foi baseada em documentos, questionários, bibliografia especializada, entrevistas e participaçāo em reuniōes, com o objetivo de conhecer a realidade sócio-econômica da população local. Cosntatou-se que o Municipio de Santo Antônio do Pinhal representa um modelo de turismo ambiental de base local e respeita o desenvolvimento sustentável. Os resultados desta pesquisa permitem a análise do potencial de aplicabilidade desses processos em outras áreas com as mesmas caracteristicas.

Palavras-chave: Meio ambiente, turismo ambiental

\section{Li Indicadores da resiliência do Latossolo Vermelho Escuro cultivado com citros e eucaliptos em Itapetininga SP: recuperação de um solo degradado pela compactação}

\section{Luiz Toledo Barros Rizzo}

O objetivo desta tese foi verificar a reversibilidade da compactação do latossolo vermeIho escuro sob cultivo de citros com cobertura verde de capim braquiária na rua e a adição desta palha na linha de plantio em um perfil com 30 meses e outro aos 78 meses neste tipo de manejo, em comparaçāo com o eucalipto plantado há 10 meses no mesmo tipo de solo nas condiçóes da Fazenda Monte verde em Itapetininga-SP $\left(23^{\circ} 15^{\prime}\right.$ sul, $23^{\circ} 30^{\prime}$ long. oeste). O histórico da área indicou a remoçāo de uma floresta de eucalipto plantada há aproximadamente 30 anos, na qual foram realizados no minimo três cortes. Essa seqüència de operaçōes mecanizadas (inclusive em periodos úmidos do ano para o cumprimento do cronograma de implantaçāo do empreendimento) causariam danos severos ao solo pela compactação dos horizontes superficiais, por vezes em até $1 \mathrm{~m}$ de profundidade. Para se desenvolver tal pesquisa elegeu-se um enfoque qualitativo com ênfase na morfologia do solo e secundariamente, na busca dos demais indicadores de natureza físico-hidrica, quimica, biológica e bioquimica dos processos de resiliéncia do manejo do solo ao longo do tempo, nesse sentido e momento já com um enfoque multidisciplinar. Foram eleitos 12 indicadores para verificar a resiliència da estrutura do solo compactado a saber: 1) Morfologia (descriçāo do perfil cultural), 2) Micromorfologia (observaçōes de seçōes delgados ao microscópio petrográficol 3) Agregados estáveis em água 4) Densidade aparente, 5) Porosidade total, 6) Macroporosidade 6) Micro- 
porosidade 7) Curva de retençāo da água, 8) Biomassa microbiana 9) Teor de Polissacarídeos, 10) Resistência do solo (curva de penetrómetro de impacto), 11) Freqüència de entomofauna (coleópteros de solo). Destes 1 e 2 dizem respeito a morfologia (aspectos qualitativos), 3 a 8 são de natureza fisico-hidrica ( relacionados ao funcionamento do solo) 9 e 10 de natureza bioquimica (refletindo as condiçōes fisico quimicas), 11 relacionado a resisténcia mecânica a penetração radicular, e o último(12) a um indicador biológico da mesofauna que reflete um nicho ecológico. As principais conclusỏes obtidas são:

Os estudos evidenciaram que ocorrem resiliência(recuperaçāo da estrutura física) ao longo do tempo nos diferentes perfis cultivados com capim braquiária e cobertura morta de palha

Há ação direta da graminea através do crescimento do sistema tradicular fasciculado nas fissuras naturais de desidrataçāo do perfil, progressivamente gerando muitos bioporos, resultando na fissuração intensa das camadas inicialmente compactadas.

A desidratação pontual do solo pela absorçāo do sistema radicular do capim braquiária, a pressão de crescimento das raizes, a atividade de rizosfera revelada pelo teor de polissacarideos

\section{Sistema pedológico \\ latossolo-argissolo e seu comportamento físico-hídrico em Mamboré-PR}

\section{Ari Zago}

Este trabalho foi desenvolvido na regiāo NW do Paraná, na vertente esquerda do córrego do pensamento microbacia representativa da regiào, tanto em termos de solos como de histórico de uso. Os manejos inadequados, que promoveram a perda da de fertilidade e a conseqüente erosāo, estavam ligadas as práticas conservacionistas tradicionais, que nāo levaram em conta a e biomassa microbiana são fatores ativos de reestruturaçāo que aumentam consideravelmente o diámetro dos agregados do solo.

A geraçāo de polissacarideos resultante da decomposição desta matéria orgânica da paIha tem grande efeito na microagregaçāo, especialmente nas camadas superficias do solo.

Os processos envolvidos na resiliencia da estrutura do solo sob cobertura de capim braquiária e sua palha são função do tempo, pois a estrutura é um atributo dinâmico no perfil do solo.

Os indicadores morfológicos e micromorfológicos da estrutura expressam melhor as modificaçōes em sub-superficie do que a análise multivariada de componentes principais.

Entre 12 indicadores eleitos para verificar a resiliência, a morfologia descrita através do método do perfil cultural, a resistencia do solo a penetração e a observação dos vestigios da entomofauna de coleópteros do solo ( corós ) sāo os melhores, imediatos e seguros indicadores da estrutura do Latossolo Vermelho Escuro tesxtura muito argilosa na Fazenda Monte Verde em Itapetininga-SP.

Palavras-chave: Solos-manejo, solos-degradados, solos-recuperação, solos-compactação, solos-tropicais

sucessão lateral de Latossolos para Argissolos.

Esta pesquisa partiu de um estudo em toposeqüência, em que o "continuum"de cobertura pedológica foi observado, seguido do estudo macro e micromorfológico de dois perfis (Latossolo-Argissolo) e foi acompanhado de análises rotineiras de Laboratório bem como em campo (tensiometria e infiltrometria), onde a instalaçāo dos equipamentos foi feita em função da re. ferida sucessāo lateral, em cinco estaçōes.

Os resultados físicos, os físico-hídricos de laboaratório e as observações de campo permitiram constatar que ocorreu e, ainda ocorre, uma transformaçāo pedológica lateral de jusante a 
montante no desenvolvimento do Argissolo, adentrando, já, na meia encosta, às expensas dos Latossolos.

As caracterizaçōes macro e micromorfológicas demonstraram um desenvolvimento de macro estrutura fraca a moderada e, também. uma microestrutura enáulica, no Latossolo, com porosidade de empilhamento simples e comunicante. Isso favorece a infiltraçāo de água e escoamento lateral, que promoveram a remoçāo superficial e o transporte de materiais finos, dando origem na vertente, aos horizontes $\mathrm{E}$, arenosos e com uma microestrutura mónica a quitogefúrica, por concentraçāo residual de areia e a formação de horizontes Bt texturais com mais argila e microestruturas porfíricas, com porosidade fissural e cavitária.

Constatou-se fluxos hidricos verticais, nos Latossolos e a ocorrência de uma camada compactada ou endurecida, logo após a superficie. Esses fatos confirmam a hipótese inicial da meia encosta à jusante, nos Argissolos, predominaram fluxos hídricos laterais, como conseqüència das mudanças texturais, das estruturais e dados fisicos diferentes, nos horizontes $\mathrm{E}$ e Bt. Esses fluxos redistribuiram as águas ao longo da vertente e propiciaram um lençol suspenso temporário, no Argissolo entre os horizontes $\mathrm{E}$ e Bt, durante a estação chuvosa.

A determinação da macroporosidade, para solos arenosos variou numa tensāo equivalente entre 25 a $50 \mathrm{~cm}$ de altura de água. Os resultados sugerem que, para esses solos, $40 \mathrm{~cm}$ seja a altura ideal.

Em sintese, pode-se dizer que os dados obtidos revelam que a morfologia diferenciada vertical e lateral da maior parte do sistema pedológico, com comportamento físico-hídrico diferenciado, necessita de manejo apropriado. Esse manejo nāo pode estar associado a práticas uniformes, para toda a vertente, pois há necessidade de controlar os fluxos laterais subsuperficiais.

Palavras chave: Mamborè (PR), sistema pedológico Latossolo-Argissolo, toposseqüencia, morfologia, micromorfologia, tensiometria, infiltrometria, fluxos hidricos, manejo de solos

\section{Tedogênese no topo do platô de Bauru - SP: O caso da Bacia do Córrego da Ponte Preta}

\section{Leonardo José Cordeiro Santos}

O presente trabalho objetivou identificar os processos pedogenéticos responsáveis pela formaçāo dos Podzólicos na bacia hidrgráfica do Córrego da Ponte Preta, afluente do Rio Bauru, e suas relaçōes com a evoluçāo das vertentes.

A bacia do Córrego da Ponte Preta está localizada no topo do platô de Bauru, próximo a cidade do mesmo nome, na regiāo central do Estado de São Paulo, sobre arenitos da formaçāo Adamantina do Grupo Bauru (cretáceo), associado a solos do tipo Latossolo, Podzólico e Glei.
Um mapeamento morfopedólogico realizado anteriormente, serviu como base para o entendimento do meio físico e a escolha da referida bacia hidrográfica, bem como dos eixos topográficos para o estudo morfológico dos solos, através de três toposeqüências, conforme da Análise Estrutural da Cobertura Pedológica.

O estudo enfatizou a descriçāo morfológica detalhada de vários perfis ao longo das toposeqüencias, onde foram coletadas amostras deformadas e indeformadas para análises de laboratório, com destaque para as análises micromorfológica, sem prescindir das análises convencionais e fisico-hidricas.

Os resultados permitiram constatar que a passagem lateral dos Latossolos para os Podzólicos, não estria relacionada diretamente a uma 
transformaçào lateral, como demonstrado em outros trabalhos, mas a remoçāo dos horizontes superiores do solo, que teria exposto o substrato rochoso ao contato direto com os agentes do intemperismo, o que possibilitou supor que os so. los encontrados tenham idades distintas. A cobertura latossólica seria a mais antiga, enquanto que a cobertura podzólica seria mais recente.

\section{Ti Análise da cartografia brasileira. Bibliografia da cartografia na geografia no periodo de 1935-1997}

\section{Rosely Sampaio Archela}

Este trabalho tem por objetivo realizar uma análise da cartografia produzida pela geografia a partir da implantação dos cursos de Geografia no Brasil, com base nas publicaçōes periódicas de boletins e revistas de cartografia.

Apresenta dois volumes. O primeiro situa a cartografia na evoluçāo do pensamento geográfico e realiza uma discussāo teórica e metodológica de acordo com os principais segmentos

O clima urbano de Presidente Prudente

\section{Margarete Cristiane de Costa Trindade Amorim}

Presidente Prudente localiza-se no oeste do Estado de Sào Paulo, à $22^{\circ} 07^{\prime} 04^{\prime \prime}$ de latitude Sul e 51 22.57" de longitude Oeste, distante da capital paulista cerca de $560 \mathrm{~km}$. A hipótese testada ao longo deste trabalho refere-se aos efeitos de uma cidade localizada próxima à latitude do trópico de capricórnio, no clima local. A cidade tem aproximadamente 200.000 habitantes $e$ situa-se a cerca de $600 \mathrm{~km}$ do oceano em altitude variando de $390 \mathrm{~m}$ sobre o nivel do mar.
Os resultados mostraram ainda que embora o gênese do horizonte Bt seja inicialmente litodependente, há evidèncias também de transformaçāo lateral, a parti do horizonte $\mathrm{Bw}$, dando ao Bt um origem e evoluçāo poligenética. Tais processos estariam ligados a umidificação do clima durante o quaternário.

Palavras-chave: Pedogênese, cobertura pedológica, microformologia, transformação

da cartografia mundial, enfocando pesquisas realizadas no Brasil. O capítulo sobre o desenvolvimento histórico da cartografia brasileira contribui para melhor compreensão da participação da cartografia na geografia. Por fim, a partir de uma análise crítica da produção cartográfica da geografia, identifica as principais linhas de pesquisa cartográfica na geografia brasileira.

O segundo volume constitui um ampla Bibliografia Analítica da Cartografia Brasileira, também apresentado em cd-rom. Esta bibliografia é a primeira tentativa de agrupar a literatura cartográfica com cunho analitico, visando contribuir para a elaboraçāo de novas pesquisas.

Palavras-chave: Cartografia, geografia

Esta pesquisa foi desenvolvida a partir de dois eixos considerados fundamentais para a caracterizaçào do clima urbano. O primeiro referese à análise temporal, através dos dados coletados na Estaçāo Meteorológica da faculdade de Ciências e Tecnologia da UNESP e da literatura existente no assunto.

O segundo diz respeito à análise espacial que resultou de uma pesquisa intra-urbana e rural próxima, para explicar como os diferentes condicionantes geoecológicos e urbanos respondem à situação dos sistemas atmosféricos.

As caracteristicas da temperatura e a umidade relativa demonstraram que Presidente Prudente possui diferenças intra-urbana e rural que 
permitem demonstrar a existência de um clima urbano específico, fruto da combinaçāo do tipo de uso e ocupação do solo, com a presença ou carēncia de vegetaçāo, altitude e exposiçāo de vertentes. A associaçāo destes fatores permitiu compreender as anomalias da temperatura e da umidade relativa encontradas na pesquisa de campo em dois meses das estações extremas: janeiro (verão) e julho (inverno). Os tipos de tempos foram responsáveis pelas maiores ou menores magnitudes dos fenomenos conhecidos como ilhas de calor e ilhas de frescor, assim como as ilhas secas e úmidas.

\section{Tl Clima e percepção}

\section{Maria das Graças Barros Sartori}

A percepção do clima pelo homem influencia em seu ajustamento ao meio atmosférico. Como os individuos percebem o tempo e o clima é assunto principal no campo da percepção ambiental, influenciando nas suas sensaçōes de conforto e desconforto físico e mental. A Bioclimatologia Humana estuda de que maneira e por que o organismo reage às mudanças nas condiçōes de tempo, e que tipo de relaçōes podem Ihe ser impostas. Na avaliação da percepçāo climática da populaçāo rural e urbana da regiāo de Santa Maria, Rio Grande do Sul, e na identificaçāo de suas reaçōes psico-fisiológicas às situaçōes de tempo, em especial ao Vento Norte regional e local, adotaram-se duas formas de abordagem, com respectivas estratégias: a climática, baseada em dois diários e horários, cartas sinóticas e imagens de satélite, para análise ritmica
Dessa forma, pode-se afirmar que Presidente Prudente, como a grande maioria das cidades brasileiras, cresceu, sem levar em consideraçāo o seu contexto climático. No contexto do relevo, o uso e a ocupação do solo, e os condicionantes geoambientais e urbanos sāo fundamentais para caracterizar as diferenças existentes no interior da própria cidade e na zona rural próxima, com o objetivo de diagnosticar as alteraçóes presentes na atmosfera urbana, a fim de contribuir com o planejamento a cidade.

Palavras-chave: Clima urbano, anomalias térmicas, umidade

e avaliação dos parâmetros atmosféricos sob dominio do Vento Norte; a perspectiva, baseada em trabalhos de campo na zona rural (de tradiçāo pastoril e colonial) e na urbana, através de seis estratégias e respectivos instrumentos para coleta de dados, envolvendo todas as faixas etárias. A metodologia utilizada, de forma inédita, possibilitou novos avanços na interpretaçāo da gènese do Vento Norte e a identificaçāo e análise de atitudes sensaçōes e significados envolvidos na percepção do tempo e do clima, bem como a avaliação da tempo-sensitividade das pessoas ao Vento Norte, incluindo a prática da interdisciplinaridade com a medicina e observaçōes em "tem. po real" A percepção ambiental e climática pelo homem são mais desenvolvidas no meio rural que no urbano e a tempo-sensitividade afeta a grande maioria da populaçāo regional, em especial a relativa ao Vento Norte. Na cidade, os individuos percebem as alteraçóes do clima urbano.

Palavras-chave: Percepçāo ambiental e climática, ambiente rural e urbano, Vento Norte 


\section{Geografia Fisica \\ Dissertaçōes de Mestrado}

\section{Distribuição de campos rupestres e cerrados de altitude na serra do Ibitipoca, sudeste de Minas Gerais}

\section{Luciana Graci Rodela}

O trabalho constitui-se em um estudo sobre a distribuição de várias subfisioinomias de vegetação de cerrados de altitude e campos rupestres e suas relações com solos, rochas, relevo e clima, na área da Serra do Ibitipoca e arredores, em escala 1:25.000. Ibitipoca situa-se entre a Serra da Mantiqueira e o Planalto de Andrelândia, no sudeste do Estado de Minas Gerais.

Estas formaçōes de vegetação, endèmicas e com grande concentração de biodiversidade, ainda sāo pouco conhecidas. As relaçōes entre a distribuição da vegetação e seus ambientes de ocor- rència foram estabelecidas por meio de comparaçōes entre as caracteristicas ambientais, as quais foram fundamentadas pelas observaçōes de campo, revisōes bibliográficas, descriçōes e análises químicas e físicas de solos e mapeamentos temáticos da área (vegetação, solos, relevo e geologia).

Para melhor caracterizar cada fisionomia, também foram realizados levantamentos de espécies dominantes por fisionomias de vegetaçāo de campos rupestres e cerrados de altitude.

Concluiu-se que as caracteristicas fisicas do ambiente (desenvolvimento de solos, relevo. clima) sāo as mais importantes na diferenciação e distribuição das fisionomias de vegetação de cerrados de altitude e campos rupestres da Serra do Ibitipoca.

Palavras-chave: Cerrados de altitude, campos rupestres, fisionomias, distribuição

\section{Processos erosivos e planejamento urbano: carta de risco de erosão das áreas urbana e periurbana do município de Franca - SP}

\section{Kátia Canil}

A ocorrencia de processos erosivos no Estado de São Paulo caracteriza um quadro de grave degradaçāo ambiental em diversos municipios. As feiçōes erosivas lineares de grande porte (ravinas e voçorocas) têm colocado moradias em situações de risco, além de provocar a destruição de infra-estrutura das áreas urbana e periurbana e impacto dos recursos hidricos pelo assoreamento dos cursos d'água. Cenários como este são comuns em Bauru, Botucatu, Marilia, Presidente Prudente, Franca e outras cidades.

Somente no municipio de Franca existem 32 feições erosivas lineares de grande porte instaladas nas áreas urbana e periurbana, causan- do prejuizos sócio-econômicos e alterando a qualidade ambiental da cidade. A partir desse conhecimento, essa pesquisa objetivou investigar os diferentes tipos de feiçōes erosivas lineares. analisar os condicionantes do meio fisico e identificar os tipos de uso e ocupação de solo que atuam diretamente na deflagração dos processos erosivos, para entāo fornecer subsidios ao planejamento urbano.

A metodologia de cartografia de risco de erosão desenvolvida pelo IPT foi adotada neste trabalho para a elaboração da Carta de Risco de Erosão das áreas urbana e periurbana do município de Franca, na escala $1: 25.000$. Esta carta é um instrumento técnico de planejamento para preservaçāo da erosāo, com indicação de áreas potenciais, pouco favoráveis e nāo apropriadas para a ocupaçāo, auxiliando na reordenação do espaço urbano.

Palavras-chave: Processos erosivos, risco, planejamento urbano 


\section{Caracterização dos elementos do meio físico e da dinâmica da Nhecolândia (Pantanal Sulmatogrossense)}

\section{Erminio Fernandes}

Esta dissertação de mestrado teve o objetivo da caracterizar os elementos do meio físico (hidrografia, relevo, solos e aspectos fisiográficos, na regiāo de Nhecolàndia. Os procedimentos adotados basearam-se na interpretação de imagens LANDSAT-TM, canais 3, 4 e 5, nas escalas 1:1 100.000 e 1:250.000 e da base cartográfica (DSG, 1975).

Em áreas previamente escolhidas foram efetuadas perfurações em topossequéncias e coletados amostras para caracterização dos materiais. Realizaram-se vários perfis topográficos que compreendessem os principais elementos do meio. Posteriormente às coletas de campo, seguiram-se os trabalhos de gabinete que constituiram na análise do material coletado em campo, tratamento automático de cartas topográficas (DSG, 1: 100.000) e imagens LANDSAT-TM. A sobreposiçāo e a interpretação dos elementos analisados permitiu distinguir 6 compartimentos: Planicie Aluvial Atual do Rio Taquari como área dispersora de drenagem; Pantanal do rio Negro. no limite sul do Leque do Taquari, é receptor de

\section{Inálise empírica da fragilidade potencial da bacia do rio Iratim - Guarapuava - PR}

\section{Edivaldo Lopes Thomaz}

O presente estudo "Análise empírica da fragilidade potencial da bacia do Rio Iratim Guarapuava-PR" tem como objetivo delimitar e caracterizar unidades do meio físico de acordo com suas respectivas fragilidade potenciais. A metodologia seguida foi Ecodinâmica que tem como base a Teoria Geral dos Sistemas. Essa me- drenagem: Área da Vazante do Corixinho com campos extensos por onde convergem vazantes oriundas dos compartimentos vizinhos; Alta Nhecolândia com seus banhados saturados d'água, nas cheias e drenagem na forma de feixes divergentes: Área de transição entre a Alta e Baixa Nhecolândia contendo elementos dos dois compartimentos; e Baixa Nhecolândia com sistema corditheira e salina e vazantes e baias.

A caracterizaçāo destes compartimentos possibilitou levantar informaçōes sobre a dinâmica atual do Pantanal da Nhecolándia. Com relação à dinâmica hídrica da regiāo, pôde-se perceber o processo diferenciado das cheias ora condicionado pela cheia do rio Paraguai, ora pela cheia do rio Taquari, este último abastecendo a Nhecolãndia através de um processo de perde de suas águas através de canais defluentes.

As formas e dimensões dos banhados sugerem que o fluxo da água segue direção NE-SW e N-S (próximo à provincia detrítica) que desaguarāo uma parte no rio Negro, outra na Baixa Nhecolāndia. Sugerem também que os banhados estāo altamente sujeitos ao comportamento oscilatório do lençol freático, que ora apresenta-se com água e ora sem água, em questōes de dias de observaçōes pelas imagens LANDSAT-TM. Palavras-chave: Pantanal, Nhecolândia, dinâmica, meio físico, geomorfologia

todologia tem como princípio o estudo integrado contemplando a sociedade e a natureza. Para se obter as unidades de fragilidade dividiu-se o trabalho em duas etapas: na primeira foi caracterizado e cartografado os elementos da natureza (relevo, solo, clima etc.), bem como os elementos da sociedade acerca do processo de organizaçāo do espaço, representado principalmente pelo uso da terra, essa etapa se configura pela análise; na Segunda etapa (sintese) correlacionou-se as cartas temáticas (relevo, uso da terra e solo) obtendo-se uma carta sintese indicando a fragilidade potencial de cada unidade. A bacia 
do Rio Iratim possui dois compartimentos, do médio para o alto curso estāo as áreas mais bem preservadas, portanto com baixa fragilidade, por outro lado, do médio para o baixo curso encontram-se as áreas mais frágeis. Entre as unidades delimitadas as formas de relevo vertentes retilineas sāo as que apresentam maior fragilidade. O uso da terra no âmbito da bacia em muitos casos nāo segue as aptidóes morfopedológicas (relevo-solo), havendo assim, áreas degradadas

\section{Tr Análise empírica da fragilidade potencial da bacia do rio Iratim - Guarapuava - PR}

\section{Edivaldo Lopes Thomaz}

O presente estudo, "Análise empírica da fragilidade potencial da bacia do Rio Iratim Guarapuava-PR" tem como objetivo delimitar e caracterizar unidades do meio fisico de acordo com suas respectivas fragilidade potenciais. A metodologia seguida foi Ecodinàmica que tem como base a Teoria Geral dos Sistemas. Essa metodologia tem como princípio o estudo integrado contemplando a sociedade e a natureza. Para se obter as unidades de fragilidade dividiu-se o trabalho em duas etapas: na primeira foi caracterizado e cartografado os elementos da natureza (relevo, solo, clima etc.), bem como os elementos da sociedade acerca do processo de organizaçào do espaço, representado principalmente pelo uso da terra, essa etapa se configura pela análise; na Segunda etapa (sintese) correlacionou-se as car-

Análise ambiental urbana: sub-bacias do córrego Marmeleiro e alto do ribeirão Moinho Velho - Cotia/Embú - SP

\section{José Mariano Caccia Gouveia}

Entende-se que a paisagem possui um caráter dināmico por considerar todas as inte- em que os solos perderam a capacidade de suporte de biomassa. Dessa forma, a presente pesquisa ao delimitar, caracterizar unidades do meio fisico e compreender de forma coerente a dinámica ambiental da bacia do Rio Iratim oferece um zoneamento ambiental que possibilita o uso adequado de seus recursos naturais, principalmente solo e água.

Palavras-chave: Geografia, bacia hidrográfica,ecodinàmica, fragilidade, geomorfologia ambiental

tas temáticas (relevo, uso da terra e solo) obtendo-se uma carta sintese indicando a fragilidade potencial de cada unidade. A bacia do Rio Iratim possui dois compartimentos, do médio para o alto curso estão as áreas mais bem preservadas, portanto com baixa fragilidade, por outro lado, do médio para o baixo curso encontram-se as áreas mais frágeis. Entre as unidades delimitadas as formas de relevo vertentes retilineas sāo as que apresentam maior fragilidade. O uso da terra no âmbito da bacia em muitos casos não seguem as aptidōes morfopedológicas (relevo-solo), havendo assim, áreas degradadas em que os solos perderam a capacidade de suporte de biomassa. Dessa forma, a presente pesquisa ao delimitar, caracterizar unidades do meio fisico e compreender de forma coerente a dinâmica ambiental da bacia do Rio Iratim, oferece um zoneamento ambiental que possibilita o uso adequado de seus recursos naturais, principalmente solo e água.

Palavras-chave: Geografia, bacia hidrográfica, ecodinàmica, fragilidade, geomorfologia ambiental

raçōes entre os aspectos físicos, bióticos e humanos inseridos nas dimensões espaço e tempo. Pretende-se neste trabalho desenvolver uma análise ambiental à partir dos diversos componentes da paisagem observados na área de estudo. considerando também a forma como tem ocorri. do seu processo de ocupação ao longo das últimas décadas. 
Nesse sentido elegeu-se como área de estudo para a elaboração da análise, os terrenos degradados pelo Córrego do Marmeleiro e pelo alto Ribeirão Moinho Velho, duas sub-bacias Iocalizadas na porçāo Oeste da Regiāo Metropolitana de São Paulo pertencentes aos municípios de Embú e Cotia.

Constata-se na área um processo de ocupaçāo em ritmo acelerado, resultando num mosaico bastante diversificado. Esse crescimento vertiginoso vem ocorrendo às custas de uma progressiva alteração meio físico-biótico, das condiçóes ambientais e da qualidade de vida da populaçāo.

Assim, a presente pesquisa tem como objetivo uma avaliação do quadro ambiental das sub-bacias. Esta avaliação, resultante da análise

\section{Tiagnóstico ambiental com subsídio a um gerenciamento costeiro: estudo de caso dos manguezais do rio Santana, Ilhéus, Bahia}

\section{Pedro Isaac Japiassu Fidelman}

O presente estudo apresenta diagnóstico ambiental dos manguezais do Rio Santana, llhéus, Bahia, adotando o enfoque por problema ambiental, ou seja, a degradaçāo do ecossistema em funçāo da expansāo urbana. Tal enfoque cria uma demanda por informaçóes especificas resultando em um diagnóstico funcional. Para meIhor entendimento sobre a "saúde" ambiental do ecossistema manguezal, adotou-se abordagem integrada e multi-disciplinar, de forma a reconhecer sua inter-relação com a paisagem da qual faz parte. Nesse sentido, identificou-se a necessidade de se trabalhar em um nivel hierárquico superior, isto é, a bacia hidrográfica. Foram consideradas informaçōes sobre características ecológicas, aspectos sócio-económicos, históricos e integrada dos componentes do meio físico, biótico, do processo de ocupaçāo, das diferentes formas de uso e ocupação da terra e da legislaçāo incidente na área, permitirá compreender a situaçāo atual do ambiente em questāo, identificando alterações ambientais resultantes de um processo de ocupaçāo que desconsidera eventuais restriçōes impostas por alguns desses componentes.

Acredita-se que este produto poderá fornecer subsidios aos órgāo públicos estaduais e municipais envolvidos, no sentido de nortear o planejamento da área a fim de evitar a total degradação do ambiente, bem como na adoçāo de medidas que minimizem os impactos já existentes.

Palavras-chave: Análise ambiental.

geomorfologia, fragilidade

culturais, potencialidades dos principais atores sociais envolvidos e legislação pertinente. Com perspectiva de utilização do diagnóstico como subsidio a uma possivel configuração de medidas de gestāo, os problemas levantados foram analisados de acordo com as propostas sugeridas pelo Programa Nacional de Gerenciamento Costeiro. O diagnóstico levou em conta ainda consideraçōes metodológicas amplamente empregadas no Gerenciamento Costeiro (Integrado) em nivel internacional. No municipio de llhéus, o baixo grau de organização dos atores sociais, a ineficiência na aplicação dos instrumentos de gestão disponiveis, a carência de pessoal capacitado para trato específico das questóes ambientais costeiras, os valores culturais regionais tendendo ao individualismo e ao imediatismo, a falta de vontade politica, entre outros, precisam ser superados para que qualquer programa de gestāo ambiental possa ser proposto e implementado com possibilidade de sucesso.

Palavras-chave: Diagnóstico ambiental, manguezais, gerenciamento costeiro 